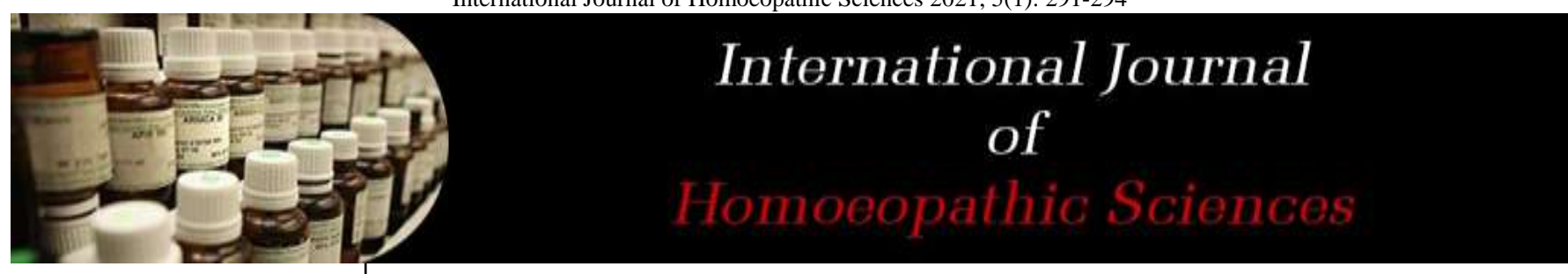

E-ISSN: $2616-4493$ P-ISSN: 2616-4485 www.homoeopathicjournal.com IJHS 2021; 5(1): 291-294 Received: 13-12-2020 Accepted: 21-01-2021

Dr. Dharmendra Kumar PGT, Department of Materia Medica, RBTS Govt Homoeopathic Medical College and Hospital, Bihar. India
Corresponding Author: Dr. Dharmendra Kumar PGT, Department of Materia Medica, RBTS Govt Homoeopathic Medical College and Hospital, Bihar, India

\section{Homoeopathy and its approach on cancer}

\section{Dr. Dharmendra Kumar}

DOI: $\underline{\text { https://doi.org/10.33545/26164485.2021.v5.i1e.328 }}$

\section{Abstract}

Patients with malignant growth generally utilize corresponding and integrative medication, including homeopathy. Homeopathy has developed in prevalence with people in general yet is seen with doubt by clinical scholarly community is as yet rejected from routinely recommended medicines. Lately, homeopathy has been utilized in malignant growth care in Europe and different nations around the world. This utilization brought up the issue if there is any advantage in using this kind of care with malignant growth patients.

Keywords: Cancer, homoeopathy, Materia Medica

\section{Introduction}

As today we are not, at this point unconscious about "malignancy". It is spreading in all aspects of world so quick that the worldwide malignancy trouble is assessed energetically. We need to set ourselves up for an answer for at least back it off and afterward discover its cycle of help.

Homeopathy is an integral and elective medication methodology that includes the utilization of items, gotten from exceptionally weakened vegetable, creature or mineral fixings, for the end of specific problems in the body. Homeopathy is at present one of the 10 elective operations most generally utilized by malignancy patients.

How Cancer Arises: Cancer is caused by certain changes to genes, the basic physical units of inheritance. Genes are arranged in long strands of tightly packed DNA called chromosomes. Cancer is a genetic disease that is, it is caused by changes to genes that control the way our cells function, especially how they grow and divide.

Genetic changes that cause cancer can be inherited from our parents. They can also arise during a person's lifetime as a result of errors that occur as cells divide or because of damage to genetic DNA caused by certain environmental exposures.

\section{When Cancer Spreads}

In metastasis, malignant growth cells split away from where they initially shaped (essential disease), travel through the blood or lymph framework, and structure new tumors (metastatic tumors) in different pieces of the body.

\section{Types of Cancer}

There are more than 100 types of cancer. Types of cancer are usually named for the organs or tissues where the cancers form.

Here are some categories of cancers that begin in specific types of cells:

\section{Carcinoma}

Carcinomas are the most common type of cancer. They are formed by epithelial cells, which are the cells that cover the inside and outside surfaces of the body.

Carcinomas that begin in different epithelial cell types have specific names:

Adenocarcinoma is a cancer that forms in epithelial cells that produce fluids or mucus. Most cancers of the breast, colon, and prostate are adenocarcinomas.

Basal cell carcinoma is a cancer that begins in the lower or basal (base) layer of the epidermis, which is a person's outer layer of skin.

Squamous cell carcinoma is a cancer that forms in squamous cells, which are epithelial cells that lie just beneath the outer surface of the skin. 
Squamous cells also line many other organs, including the stomach, intestines, lungs, bladder, and kidneys. Squamous cells look flat, like fish scales, when viewed under a microscope. Squamous cell carcinomas are sometimes called epidermoid carcinomas.

Transitional cell carcinoma is a cancer that forms in a type of epithelial tissue called transitional epithelium, or urothelium. This tissue, which is made up of many layers of epithelial cells that can get bigger and smaller, is found in the linings of the bladder, ureters, and part of the kidneys (renal pelvis), and a few other organs.

\section{Sarcoma}

Soft tissue sarcoma forms in soft tissues of the body, including muscle, tendons, fat, blood vessels, lymph vessels, nerves, and tissue around joints.

\section{Leukemia}

Cancers that begin in the blood-forming tissue of the bone marrow are called leukemias. These cancers do not form solid tumors. Instead, large numbers of abnormal white blood cells (leukemia cells and leukemic blast cells) build up in the blood and bone marrow, crowding out normal blood cells.

\section{Lymphoma}

Lymphoma is cancer that begins in lymphocytes ( $\mathrm{T}$ cells or B cells).In lymphoma abnormal lymphocytes build up in lymph nodes and lymph vessels, as well as in other organs of the body.

\section{There are two main types of lymphoma}

Hodgkins lymphoma: People with this disease have abnormal lymphocytes that are called Reed-Sternberg cells. These cells usually form from B cells.

Non-Hodgkins lymphoma: This is a large group of cancers that start in lymphocytes. The cancers can grow quickly or slowly and can form from B cells or T cells.

\section{Multiple Myeloma}

Multiple myeloma is cancer that begins in plasma another type of immune cell. The abnormal plasma cells, called myeloma cells, build up in the bone marrow and form tumors in bones all through the body.

\section{Melanoma}

Melanoma is cancer that begins in cells that become melanocytes, which are specialized cells that make melanin (the pigment that gives skin its color). Most melanomas form on the skin, but melanomas can also form in other pigmented tissues, such as the eye.

\section{Brain and Spinal Cord Tumors}

There are different types of brain and spinal cord tumors. These tumors are named based on the type of cell in which they formed and where the tumor first formed in the central nervous system.

\section{Other Types of Tumors \\ Germ Cell Tumors}

Germ cell tumors are a type of tumor that begins in the cells that give rise to sperm or eggs. These tumors can occur almost anywhere in the body and can be either benign or malignant.

\section{Neuroendocrine Tumors}

Neuroendocrine tumors form from cells that release hormones into the blood in response to a signal from the nervous system.

\section{Carcinoid Tumours}

Carcinoid tumors are a type of neuroendocrine tumor. They are slow-growing tumors that are usually found in the gastrointestinal system (most often in the rectum and small intestine).

\section{Some Homoeopathic Remedies from Boericke Materia Medica}

Asterias Rubens: Cancer mammae even ulcerative stage.it states acute lancinating pain. Axillary glands swollen hands and knotted.

Carbo Animalis: Burning pain down thighs, uterine cancer. Nose swollen, tip bluish, small tumour on it.

Carduus Marianus: Useful in profuse diarrhoea due to rectal cancer.

Cistus Canadensis: Lupus, caries; open, bleeding cancer. The neck is studded with tumors, malignant disease of the glands of the neck.

Cundurango: Allays the pain in gastralgia accompanying cancer of stomach, chronic gastric catarrah, syphilis and cancer. Ulcerative stage of carcinoma cutis when fissures form. Tumors, stricture of oesophagus.

Corydalis Formosa: Cancer cachexia pronounced.

Crotalus Horridus: Cancer of tongue with haemorrhage, cancer of stomach with vomiting of bloody, slimy mucus.

Echinacea Augustifolia: Last stages of cancer to ease pain.

Fuligo Ligni: Chronic irritations of mucous membranes of mouth; pruritis vulvae; uterine haemorrhage; cancer especially of scrotum (chimney sweeper's cancer), epithelial cancers; cancer of womb with metrorrhagia; sadness, thoughts of suicide.

Galium Aparine: Has power of suspending or modifying cancerous action. Has clinical confirmation of its use in cancerous ulcers and nodulated tumors of tongue.

Graphitis: Cancer of pylorus.

Hoang Nan: Cancer of glandular structures. Removes fetor and haemorrhage in cancer, it revives the healing process.

Hydrastis Canadensis: Cancer and cancerous state, before ulcerations, when pain is the principal symptom. Ulcers and cancer of stomach. Tumor of breasts, nipples retracted. Cancerous formations in skin.

Hydrocotyle Asiastica: Pain of cervical cancer.

Kalium Arsenicum: Skin cancer where suddenly an alarming malignancy without any external signs sets in. 
Kalium Cynatum: Cancer of tongue and agonizing neuralgia have been benefited by this drug.

Kalium Phosphoricum: After removal of cancer when in healing process the skin is drawn tight over the wound. Suspected malignant tumors.

Malandrium: Efficacious in cleaning the remnants of cancerous deposits.

Ornithogalum Umbellatum: Considered in chronic gastric and other abdominal indurations, possibly cancer of intestinal tract specially of stomach and caecum.

Phosphoricum Acidum: Useful in relieving pains of cancer.

Phytolacca Decandra: Tumors of the breasts with enlarged axillary glands, cancer of breasts.

Sangunaria Canadesis: Cancer of rectum.

Taraxacum Officinale: Cancer of bladder.

Cadmium Sulphuratum: Carcinoma ventriculi; persistent vomiting.

Carcinosinum: History of carcinoma. Carcinoma of the mammary glands with great pain and induration of glands; of uterus, the offensive discharge, haemorrhage and pains are greatly relieved.

Euphorbium Officinarum: Ulcerating carcinoma and epithelioma of the skin.

Lapis Albus: Pre-ulcerative stage of carcinoma, uterine carcinoma. Fibroid tumors with intense burning pains through the part with profuse haemorrhage.

Ruta Graveoleus: Carcinoma affecting lower bowel.

Formic Acid: Carcinoma of stomach and breasts.

Calcarea Fluorica: Blood tumors of new born infants. Chief remedy for vascular tumors with dilated blood vessels and for varicose or enlarged veins. Osseus tumors. Ganglia or encysted tumors at the back of the wrist.

Calcarea Sulphurica: Cystic tumors.

Chimaphila Umbellata: Painful tumor of mammae, not ulcerated with undue secretion of milk. Women with very large breasts and tumors in the mammary gland with sharp pains through it.

Chronicum Acidum: Post-nasal tumors and epithelioma of the tongue have been benefited by this drug.

Clematis Erecta: Glandular indurations and tumors of breast.
Colocynthis: Round, small cystic tumors in ovaries or broad ligaments.

Conium Maculatum: Skin tumors; piercing pains, worse at night.

Fraxinus Americana: Uterine tumors with bearing down sensations.

Gossypium Herbaceum: Tumor of the breast with swelling of axillary glands.

Kalium Bromatum: Cystic tumors of ovaries.

Kalium Iodatum: Bony tumors of the orbit.

Mercurialis Perennius: Tumor at ensiform appendix, very sensitive.

Mercurius Auratus: Brain tumors.

Mercurius Iodatum Flavus: Mammary tumors with tendency to much warm perspiration and gastric disturbances.

Natrium Silicofluoricum: A cancer remedy, tumors.

Platanus Occidentalis: Tarsal tumors.

Scrophularia Nodosa: Very useful in the dissipation of breast tumors. Nodositis in the breast

Silica Terra: Indurated tumors

Teucrium Marum Verum: Tarsal tumors (staph).

Thuja Occidentalis: Tarsal tumors.

Thyroidinum: Mammary tumors. Fibroid tumors of the breasts.

Anilinum: Tumors of the urinary passages.

Belladonna: Tumors of breast pain worse lying down.

Berberis Aquafolium: Tumor of breasts with pain.

Bromium: Tumor in breasts with stitching pains, worse left.

Bufo Rana: Tumors and polypi of womb.

Eucalyptus Globulus: Malignant disease of stomach with vomiting of blood and sour fluid.

Lobelia Erinus: Malignant growths, extremely rapid development, colloid cancer of the omentum; cork-screw like pains in abdomen. Malignant disease of the face. Epithelioma. 
Table 1: Miasmatic clinical tips

\begin{tabular}{|c|c|c|c|}
\hline Psoric cancer & Sycotic cancer & Syphilitic cancer & Tubercular Cancer \\
\hline $\begin{array}{c}\text { Psora is responsible for } \\
\text { deficiency, which leads to } \\
\text { deficiency in immunity. The } \\
\text { cancer caused by continuous } \\
\text { physical and emotional irritation } \\
\begin{array}{c}\text { and it is the lowered immunity, } \\
\text { which makes the person }\end{array}\end{array}$ & $\begin{array}{c}\text { Sycosis is responsible for } \\
\text { hypertrophy, the cells proliferate } \\
\text { and tumours are formed. Initially } \\
\text { the tumours are benign and } \\
\text { vulnerable to such irritation. }\end{array}$ & $\begin{array}{c}\text { Syphilis is responsible for } \\
\text { destruction, disintegration and } \\
\text { degeneration. The malignant } \\
\text { property of the cells leads to } \\
\text { necrosis followed by pus }\end{array}$ & $\begin{array}{c}\text { It is responsible for the } \\
\text { migration and } \\
\text { haemorrhage. } \\
\text { Disintegrated and } \\
\text { degenerated cells } \\
\text { haemorrhage and then } \\
\text { migrate resulting in } \\
\text { metastasis. }\end{array}$ \\
\hline
\end{tabular}

\section{Conclusion}

Homoeopathy plays the vital role on the treatment of cancer. The basic needs of the person are to makes the life healthy and happy. Homoeopathic treatment effects the man's internally and individualise each person by his/her constitution. In homoeopathic science we treat the patient, not the disease. But more research is needed in this topic to make \& show good results in the upcoming years.

\section{References}

1. Banerjee Subrata Kumar. Miasmatic Prescribing.

2. Hahnemann CFS. Chronic diseases, B. Jain Publishers Pvt. Ltd., New Delhi I-II.

3. Hahnemann CFS. Organon of Medicine, $5^{\text {th }} \& 6^{\text {th }}$ edition; $5^{\text {th }}$ impression, B. Jain Publishers Pvt. Ltd., New Delhi 2009.

4. Hahnemann CFS. Lesser Writing, B. Jain Publishers Pvt. Ltd., New Delhi.

5. Boericke's New Manual of Homoeopathic Materia Medica with Repertory, $3^{\text {rd }}$ revised and augmented edition based on ninth edition. Adi BS. Efficacy of homoeopathic medicines in chronic low back pain: A clinical study. International Journal of Alternative and Complementary Medicine 2020, 17-20. Indian dermatology online journal 2014;5(4):535, 2007.

6. Kent James Tyler. Lectures on Homoeopathic Philosophy; Reprint Edition; B. Jain Publishers (P) Ltd.; New Delhi, 2005.

7. Prasanta Banerji, Pratip Banerji. Homeopathy: Treatment of Cancer with the Banerji Protocols.

8. Harsh Mohan's pathology.

9. Robins Basic Pathology. 